\title{
ANALISIS KESALAHAN PENULISAN PARAGRAF ARGUMENTASI MAHASISWA JURUSAN NON BAHASA INGGRIS POLITEKNIK NEGERI JEMBER
}

\author{
Yuslaili Ningsih \\ Jurusan Bahasa, Komunikasi, dan Pariwisata Politeknik Negeri Jember
}

\begin{abstract}
Abstrak
Ningsih, Yuslaili, 2015. Analisis Kesalahan Penulisan Paragraf Argumentasi Mahasiswa Jurusan Non Bahasa Inggris Politeknik Negeri Jember.
\end{abstract}

Berlatar belakang dari kesulitan-kesulitan mahasiswa dalam pembelajaran bahasa Inggris seperti kurangnya penguasaan kosakata, struktur kalimat, serta penulisan kalimat dalam bahasa Inggris bagi mahasiswa di jurusan-jurusan non bahasa Inggris, artikel ini bertujuan untuk membahas analisis kesalahan siswa dari beberapa aspek penulisan paragraf argumerntasi yang benar terhadap mahasiswa non bahasa Inggris Politenik Negeri Jember. Analisis ini mengenai pengukuran jenis dan frekuensi kesalahan dalam penulisan paragraf argumentasi. Hal ini sangat berguna dalam mengetahui gagasan sekaligus kemampuan siswa dalam menulis paragraf argumentasi. Analisa data penelitian ini dapat dilakukan dengan mengidentifikasi kesalahan atau penyimpangan yang dibuat siswa terhadap aspek-aspek penulisan paragraf argumentasi seperti pemakaian kosakata, grammar/struktur kalimat, isi serta pengorganisasian paragraf. Dari hasil analisa kesalahan yang terjadi dapat diketahui kemampuan siswa dalam membuat kalimat bahasa Inggris serta kecenderungan terhadap salah satu aspek apa yang mempunyai frekuensi kesalahan tertinggi ataupun terendah dalam penulisan paragraf agrumentasi. Pendekatan yang dipakai pada penelitian ini adalah descriptif quantitatif dengan sistem perhitungan statistik sederhana, sedangkan pengambilan sampel dilakukan seara acak terhadap perwakilan. Hasil dari analisa ini diharapkan dapat memberikan kontribusi kepada dosen bahasa Inggris sebagai tolok ukur pengembangan bahan ajar serta metode pengajaran yang akan diberikan dalam mata kuliah bahasa Inggris terutama writing. Disamping itu artikel ini diharapkan dapat memberikan feedback terhadap mahasiswa sebagai pembelajaran dan pengetahuan tentang penulisan paragraf argumentasi dalam bahasa Inggris.

Kata kunci: kesalahan, paragraf argumentasi bahasa Inggris, mahasiswa non-bahasa Inggris. 


\section{PENDAHULUAN}

Bahasa Inggris adalah alat komunikasi Internasional yang menjadi penghubung antar negara negara di dunia. Begitu pula bagi Indonesia yang telah memasuki era globalisasi dimana dituntut sumber daya manusia dengan kompetensi yang memadai. Kurikulum di semua jenjang atau tingkat pendidikan menempatkan Bahasa Inggris sebagai mata pelajaran wajib yang harus dipelajari oleh semua peserta didik. Bahasa Inggris sangat diperlukan untuk kesiapan lulusan di dalam memasuki persaingan dunia kerja. Hal tersebut karena kemampuan berbahasa Inggris sering dijadikan prasyarat oleh perusahaan atau institusi sebagai nilai tambah atau bahkan keharusan seseorang yang mempunyai kemampuan lebih.

Salah satu program pendidikan tinggi yang menekankan kesiapan peserta didik adalah pendidikan vokasi. Sistem pendidikan vokasi atau kejuruan menekankan keahlian untuk persiapan peserta didik dalam memasuki dunia kerja. Politeknik merupakan pendidikan tinggi yang berbasis sistem pendidikan bermuatan praktis. Oleh karena itu material ajar berdasar $60 \%$ praktek dan $40 \%$ teori, termasuk di dalamnya mata kuliah bahasa Inggris karena pembelajaran bahasa Inggris merupakan pembelajaran implementasi yang mengedepankan praktek secara langsung. Sebab bahasa adalah habitual learning atau pembelajaran kebiasaan yang perlu dipraktekan langsung oleh siswa sebagai hasil belajar.

Begitu pula dalam mata kuliah bahasa Inggris yang wajib ditempuh oleh semua jurusan yang ada di Politeknik. Oleh karena keterbatasan waktu dan porsi dengan mata kuliah jurusannya, maka bahasa Inggris harus ditempuh selama satu atau maksimal dua semester saja untuk jurusan non Bahasa Inggris. Oleh sebab hal tersebut, maka sangat perlu bagi dosen pengajar Bahasa Inggris untuk memberikan pengajaran bahasa Inggris secara efektif dan efisien. Hal ini dapat dilakukan dengan mengetahui kemampuan siswa dalam menulis bahasa Inggris. Selain itu dengan menulis paragraf argumentasi bertopik 'Bahasa Inggris menurut Anda' akan diketahui opini serta motivasi mahasiswa terhadap pembelajaran bahasa Inggris secara personal. Karena hal ini sangat berpengaruh terhadap pengembangan dan inovasi materi ataupun metode pembelajaran dan pengajaran bahasa Inggris bagi mahasiswa itu sendiri terutama menulis atau writing.

Secara umum dalam belajar bahasa Inggris, mahasiswa banyak menemui kesulitankesulitan baik dari segi materi maupun waktu. Terutama dalam menguasai keahlian aktif yang meliputi speaking dan writing. Ramelan (1992) mengatakan bahwa sebagian besar masalah belajar disebabkan oleh unsur-unsur yang berbeda yang ditemukan di antara dua bahasa. Ketika seseorang belajar bahasa asing, ia sering menghadapi kendala, di mana seseorang menggunakan bahasa ibunya atau struktur bahasa pertama yang berbeda dari bahasa target.

Dasar mempelajari suatu bahasa secara garis besar berkaitan dengan komponen bahasa target yaitu vocabulary (kosakata), grammar (struktur atau tata bahasa), dan pronunciation (ejaan) yang menjadi dasar untuk menguasai kemampuan atau skill berbahasa yaitu reading (membaca), listening (mendengar), speaking (berbicara) dan writing (menulis).

Menulis adalah salah satu keterampilan yang paling rumit dan kompleks bagi siswa untuk dikuasai. Siswa diminta untuk menghasilkan huruf, kata, dan kalimat yang bisa dipahami oleh pembaca. Dalam menulis, siswa harus mampu secara efektif memilih topik, rencana, dan mengatur ide-ide. Levine (1993) menjelaskan fenomena ini mungkin terjadi karena kedua ESL dan EFL siswa tidak memiliki cukup kosakata, takut kritik, dan ingin menghindari kebingungan emosional ketika mereka menghadapi topik dan kertas kosong. 
Hal ini dilatarbelakangi oleh siswa yang umumnya hanya memiliki sedikit antusiasme untuk tugas-tugas menulis mereka karena dirasa sulit untuk mengerjakan. Sehingga mereka banyak membuat kesalahan dalam proses pembelajaran menulis. Selain itu, ada banyak faktor pembuat kesalahan dalam penulisan yang dilakukan oleh siswa. Sebagai contoh, para siswa memiliki sedikit kosakata bahasa Inggris sehingga mereka tidak tahu kata-kata yang tepat untuk ditulis, disamping itu terbatasnya pengetahuan tentang tata bahasa sehingga mereka merasa malas untuk menulis kata-kata bahasa Inggris atau kalimat juga paragraph dalam bahasa Inggris karena merasa sulit.

Fenomena tersebut bisa saja terjadi kepada mahasiswa Politeknik Negeri Jember. Dalam penelitian ini, penulis menganalisis kesalahan dalam penulisan paragraf argumentasi yang dibuat oleh mahasiswa Non Bahasa Inggris Politeknik Negeri Jember. Hal tersebut bertujuan untuk mengetahui kemampuan bahasa Inggris khususnya menulis atau writing siswa. Dari teridentifikasinya kesalahan-kesalahan yang dibuat, maka peneliti akan mengetahui jenis kesalahan apa saja yang mereka buat seperti kesalahan pada grammarnya, atau pemilihan kata, mungkin juga dari segi isi paragraf serta frekuensi kesalahan dalam penulisan paragraf argumentasi oleh mahasiswa non Bahasa Inggris Politeknik Negeri Jember.

Penelitian ini bertujuan untuk mengetahui jenis kesalahan dalam elemen penulisan argumentasi oleh mahasiswa semester 3 jurusan non bahasa Inggris Politeknik Negeri Jember. Disamping itu penelitian ini bertujuan untuk membandingkan kesalahan yang terjadi dalam komposisi tertulis paragraf argumentasi pada tulisan mahasiswa non Bahasa Inggris Politeknik Negeri Jember.

Penelitian ini diharapkan dapat memberikan kontribusi praktis untuk tumbuhnya pengetahuan dalam pembelajaran dan pengajaran Bahasa Inggris khususnya ketrampilan menulis. Sehingga pengajar akan mengetahui sampai dimana kemampuan mereka yang dapat dijadikan salah satu tolok ukur untuk memberikan materi pengajaran yang sesuai, efektif dan efisien. Secara praktis, penelitian ini diharapkan dapat membantu guru bahasa Inggris untuk mengetahui bagian mana dari organisasi paragraf argumentasi yang mereka harus perhatikan. Selain itu, dengan mengetahui kesalahan yang dibuat siswa, guru akan dapat memilih teknik serta materi yang paling tepat untuk mengatasi masalah siswa dalam memperoleh kualitas penulisan yang baik. Diharapkan pula penelitian ini akan membantu para peneliti lain untuk melakukan penelitian lebih lanjut dengan lebih baik.

\section{METODOLOGI}

Metode penelitian merupakan prosedur penelitian untuk mendapatkan informasi atau data dari siswa untuk kemudian dianalisa dan diolah untuk mendapatkan hasil yang akurat. Penelitian ini menggunakan desain deskriptif kuantitatif, dengan menggunakan hitungan sederhana atau disebut penampang survei. Tidak ada pengujian hipotesis dalam penelitian ini seperti yang biasa diterapkan bagi para peneliti yang menggunakan desain penelitian kuantitatif. Kesalahan yang ditemukan dalam penelitian ini diukur dengan menggunakan hitungan sederhana, karena penelitian ini tidak mengukur prestasi secara tertulis tetapi hanya untuk mengetahui kesalahan elemen dalam penulisan paragraf argumentasi siswa. Dalam analisa penelitian ini akan diketahui jenis kesalahan yang dibuat oleh siswa dan diidentifikasi jenis kesalahan yang paling sering muncul untuk kemudian dihitung prosentasenya. 


\section{Populasi dan Sampel}

Populasi didefinisikan sebagai semua anggota dari setiap kelas yang teridentifikasi baik orang, kejadian, atau benda, yaitu generalisasi dari kelompok yang lebih besar, sedangkan sampel adalah kelompok kecil atau sebagian dari populasi yang diamati (Ary at all , 2002). Populasi penelitian ini meliputi mahasiswa non bahasa Inggris Politeknik negeri Jember yang meliputi 6 jurusan non bahasa Inggris . Dalam penelitian ini, peneliti mengambil 10\% dari jumlah siswa tiap jurusan sebagai sampel penelitian ini. Penelitian ini adalah cross sectional survey yang mengumpulkan data untuk membuat kesimpulan tentang populasi (natural) pada satu titik sekaligus (Hall: 2013). Peneliti mengambil sampel dari penelitian ini secara acak karena homogenitas mahasiswa sehingga setiap individu mendapat kesempatan yang sama untuk dipilih sebagai sampel.

\section{Instrumen Penelitian}

Sebuah instrumen penelitian adalah cara untuk mendapatkan data. Ada beberapa jenis instrumen penelitian yang dapat digunakan untuk mendapatkan data, seperti: tes, kuesioner, wawancara, observasi, dokumen, dll. Arikunto (1998) menyatakan bahwa instrumen adalah perangkat atau fasilitas yang digunakan dalam mengumpulkan data atau informasi sehingga dapat mempermudah perolehan data penelitian dengan mudah dan hasilnya bisa lebih baik. Instrumen utama yang digunakan peneliti dalam penelitian ini adalah pedoman penulisan argumentasi. Pedoman argumentasi adalah arah penulisan koreksi yang sesuai dengan kriteria penulisan paragraf argumantasi yang baik. Selain itu peneliti juga menggunakan tes untuk mengetahui tulisan siswa sebagai pelaksanaan penelitian. Disamping itu sebagai instrumen penunjang, peneliti menggunakan wawancara untuk mendapatkan informasi proses belajar mengajar Bahasa Inggris di jurusan nonbahasa Inggris. Wawancara dilakukan terhadap dosen pengampu di tiap jurusan.

\section{Sumber Data}

Data dari penelitian ini berasal dari hasil tulisan atau tes menulis paragraf argumentasi bahasa Inggris siswa dalam bentuk paragraf. Tulisan paragraf argumentatif dilaksanakan mahasiswa secara langsung selama 1 jam dari durasi 2 jam praktikum. Selain itu, data mengenai aspek utama dari kemampuan menulis siswa yang harus dikuasai mengacu pada perkuliahan writing tentang paragraf argumentatif yang sudah diberikan 1 jam sebelumnya sebagai review.

\section{Analisis data}

Peneliti mengumpulkan tulisan siswa dan dianalisis dengan cara mengidentifikasi, mengklasifikasi, dan menghitung komposisi kesalahan dalam tulisan atau hasil tes. Dalam menganalisis data, penulis menerapkan beberapa prosedur. Pertama, penulis mengidentifikasi penyimpangan dalam tulisan-tulisan argumentasi. Penulis membaca hasil tes siswa dan menemukan kesalahan dalam penulisan kalimat yang ditulis oleh siswa. Kedua, penulis mengklasifikasikan kesalahan dalam jenis atau aspek kesalahan dalam menulis paragraf argumentasi dalam beberapa jenis seperti kesalahan dalam konten atau isi, kesalahan dalam pengorganisasian paragraf, kesalahan dalam kosa kata, dan kesalahan dalam tata bahasa. Terakhir, penulis menghitung frekuensi kesalahan atau eror yang terjadi dengan diidentifikasi, diklasifikasikan, dihitung, dan ditabulasikan. Pertimbangan menggunakan scoring analitik diadaptasi dari Cohen (1994) dan Coffin dkk (2003. ). 


\section{HASIL DAN PEMBAHASAN}

\section{Hasil}

Setelah melaksanakan penelitian secara keseluruhan, hasil tes dari 100 siswa dianalisa dan dinilai sehingga hasil data yang diperoleh adalah sebagai berikut :

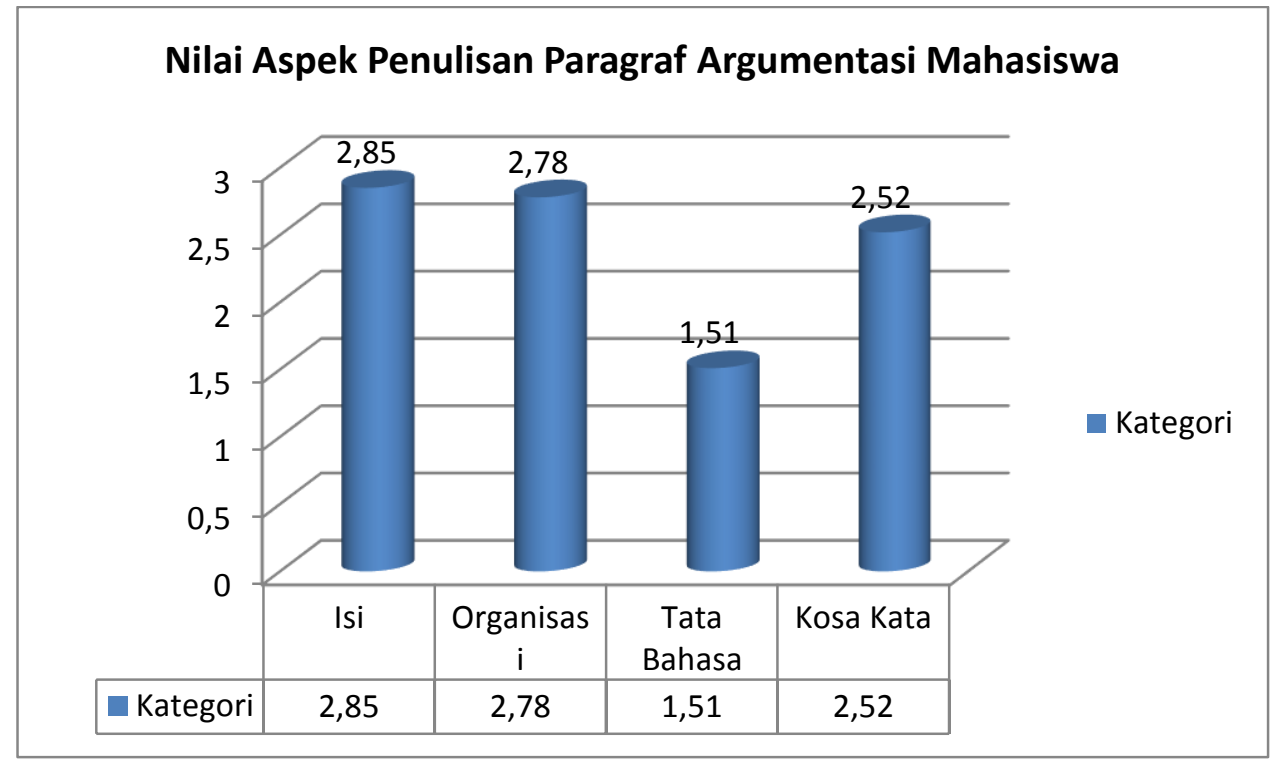

Gambar 1. Grafik Nilai Penulisan Paragraf

Argumentasi Mahasiswa

Analisa data dari 100 mahasiswa diperoleh hasil analisa kesalahan penulisan paragraf argumentasi siswa dilihat dari nilai aspek isi adalah 2,85 yang berarti berada dalam kategori cukup baik atau sama dengan kesalahan dengan nilai 50-75. Aspek organisasi mencapai ratarata 2,78 .adalah kategori cukup baik. Dianalisa dari aspek grammar atau tata bahasa rata-rata siswa membuat kesalahan dengan nilai yang cukup rendah yaitu 1,51 yang masuk dalam kategori kurang dengan rentang nilai 0-49. Sedangkan poin 2,52 ada dalam kategori cukup baik untuk nilai kosakata yang berarti kesalahan dibuat siswa pada aspek vocabulary atau kosakata tidak terlalu tinggi. Secara keseluruhan penulisan paragraf argumentasi siswa cukup baik dengan letak kesalahan tertinggi ada pada aspek grammar atau tata bahasa.

Pada dasarnya penulisan paragraf bagi mahasiswa non-bahasa Inggris merupakan hal yang mendasari kemampuan writing. Oleh sebab itu sangat perlu dilakukan latihan-latihan menulis dalam bahasa Inggris untuk mengasahnya serta mengeksplorasi penguasaan kosakata bahasa Inggris siswa. Tema Bahasa Inggris Menurut Anda adalah hal yang membutuhkan alasan-alasan dari suatu opini yang termasuk tema argumentatif. Penulisan paragraf argumentasi ini melatih ide atau gagasan kreatif siswa bila ditinjau dari segi isi. Dari hasil tes siswa pada grafik di atas diperoleh bahwa isi atau konten paragraf mendapat rata-rata poin 2,85 dengan rentang nilai antara 50-75. Hal ini menandakan bahwa ide atau gagasan mahasiswa sudah cukup baik dan cenderung dalam kategori baik atau sudah bagus. Karena poin 2 termasuk kategori cukup, sedangkan poin 3 di dalam kategori baik. Hal ini berarti poin 2,85 adalah cukup baik cenderung ke baik atau bagus sehingga bisa diartikan tingkat kesalahannya rendah. Penalaran juga diwujudkan dari aspek organisasi dimana hal ini bermakna koheren atau kesatuan ide. Paragraf argumentasi merupakan paragraf yang berdasar hal aktual dengan alasan-alasan yang menunjang ide pokok. Ditinjau dari aspek 
organisasi, poin rata-rata siswa adalah 2,78 yang termasuk dalam kategori cukup baik cenderung baik dengan kata lain tingkat kesalahan yang dibuat siswa relatif kecil. Sedangkan dari aspek grammar atau tata bahasa diperoleh poin 1,51 yang menempati kategori kurang dengan rentang nilai 0-49, di sini tampak jelas bahwa tingkat kesalahan tata bahasa yang dibuat siswa sangat besar. Hal ini berarti kesulitan belajar bahasa Inggris siswa lebih besar dalam aspek grammar.

Dari hasil wawancara dengan dosen pengampu, proses belajar mengajar bahasa Inggris berjalan dengan baik dan siswa cukup tertarik serta bersemangat terhadap bahasa Inggris, ditemukan namun demikian banyak kelemahan mendasar pada tata bahasa siswa atau grammar. Hal ini nampak pada kemampuan writing dan structure dimana sebagian besar siswa memiliki nilai yang kurang memuaskan. Sedangkan hasil wawancara dengan beberapa perwakilan siswa di tiap jurusan diperoleh informasi bahwa pada umumnya sebagian besar siswa mengalami kesulitan dalam belajar struktur tata bahasa Inggris pada umumnya, menulis atau writing English pada khususnya.

\section{Pembahasan}

Dari aspek isi, penulisan paragraf argumentasi mahasiswa dapat dilihat dari diagram pie di bawah ini:

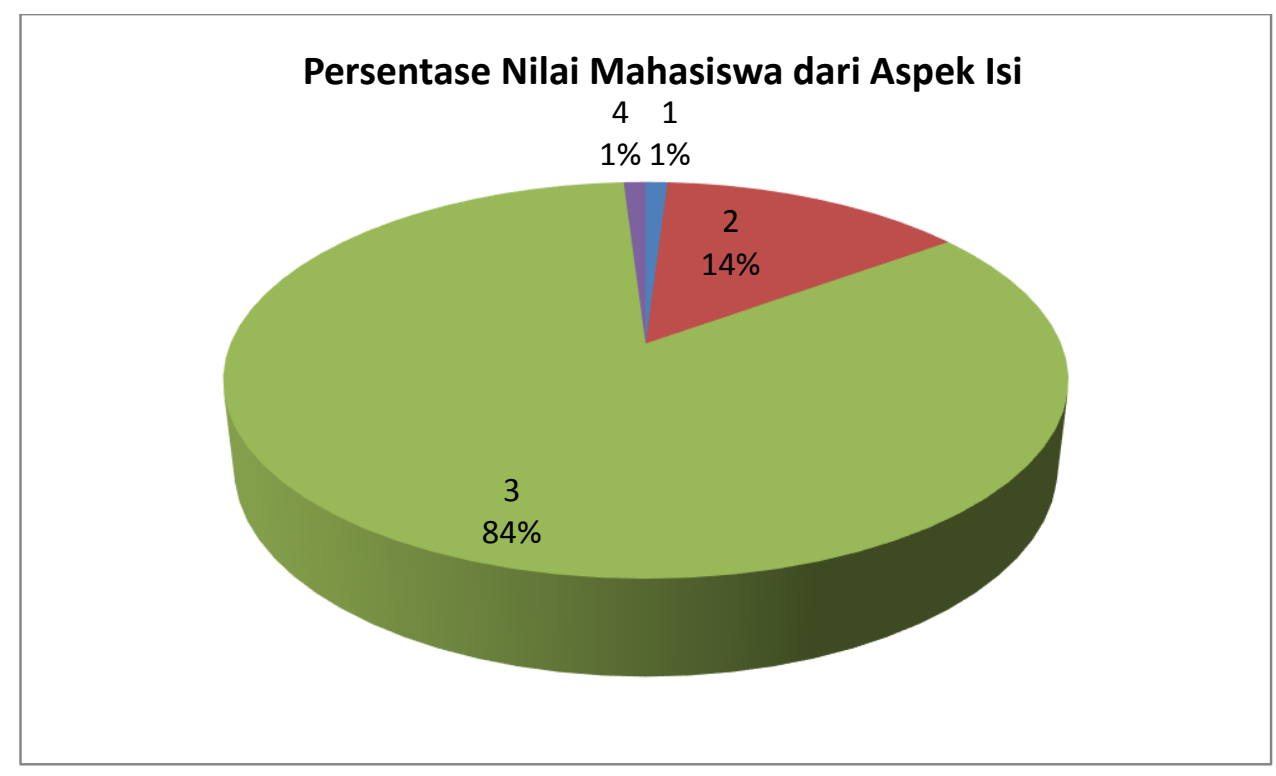

Gambar 2. Grafik Nilai Mahasiswa dari Aspek Isi

Dilihat dari diagram pie di atas maka dari 100 responden dapat diketahui bahwa mahasiswa yang mendapat nilai 1 hanya $1 \%$ dari jumlah keseluruhan responden. Sedang mahasiswa yang mendapat nilai poin 2 berjumlah $14 \%$ berkategori cukup. Mahasiswa yang mempunyai nilai poin 3 ada $84 \%$ yang merupakan kategori baik. Dan mahasiswa yang punya nilai 4 hanya $1 \%$ yang meiliki nilai tertinggi atau sangat baik pada aspek konten ini. Sehingga bisa ditarik kesimpulan bahwa pada aspek isi ini sebagian besar mahasiswa berkategori cukupbaik cenderung baik. Hal ini berarti bahwa kesalahan pada aspek konten/isi adalah rendah. 
Dari aspek organisasi, penulisan paragraf argumentasi mahasiswa dapat dilihat dari diagram pie di bawah ini:

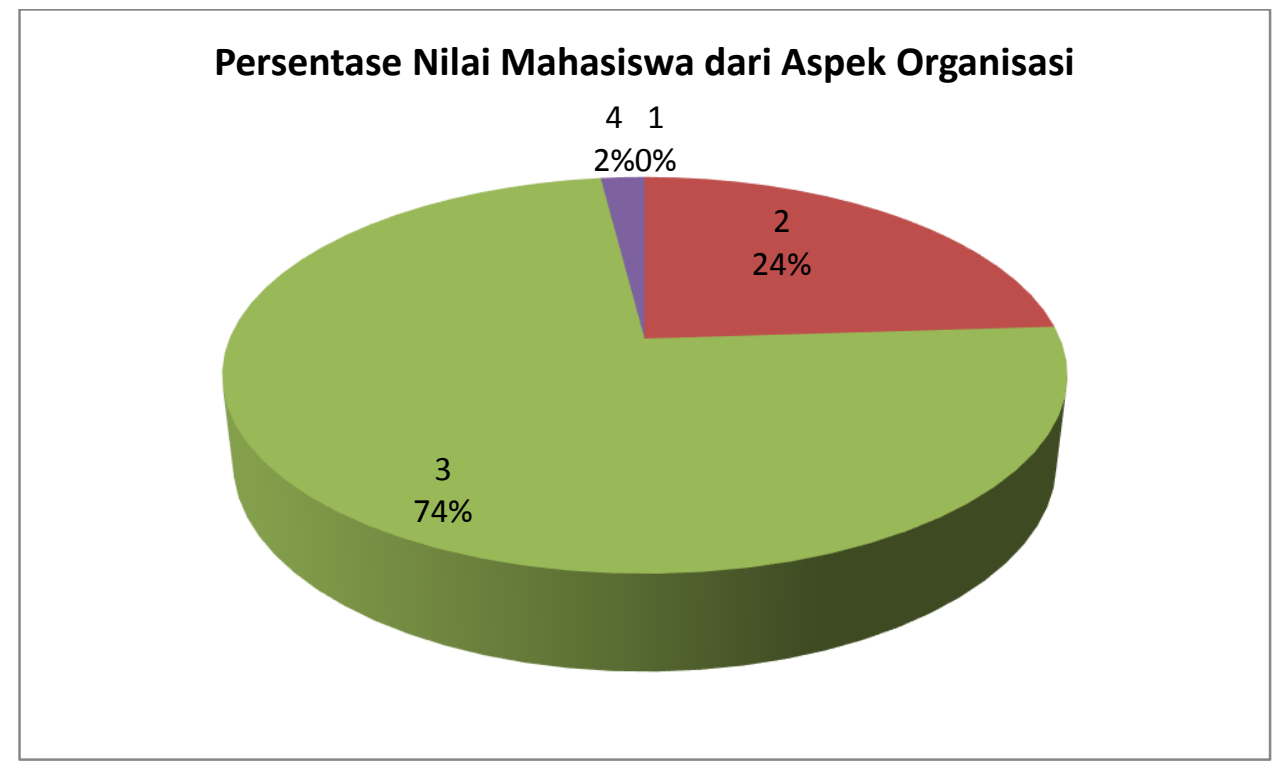

Gambar 3. Grafik Nilai Mahasiswa dari Aspek Organisasi

Dilihat dari diagram pie di atas maka dari 100 responden dapat diketahui bahwa mahasiswa yang mendapat nilai 1 tidak seorangpun. Sedang mahasiswa yang mendapat nilai poin 2 berjumlah $24 \%$ berkategori cukup. Mahasiswa yang mempunyai nilai poin 3 ada 74\% yang merupakan kategori baik. Dan mahasiswa yang punya nilai 4 atau sangat baik pada aspek organisasi ini adalah berjumlah $2 \%$.. Sehingga bisa ditarik kesimpulan bahwa pada aspek organisasi ini sebagian besar mahasiswa berkategori cukup baik dan baik. Hal ini berarti tingkat kesalahan pada aspek organisasi adalah rendah. 
Dari aspek tata bahasa, penulisan paragraf argumentasi mahasiswa dapat dilihat dari diagram pie di bawah ini:

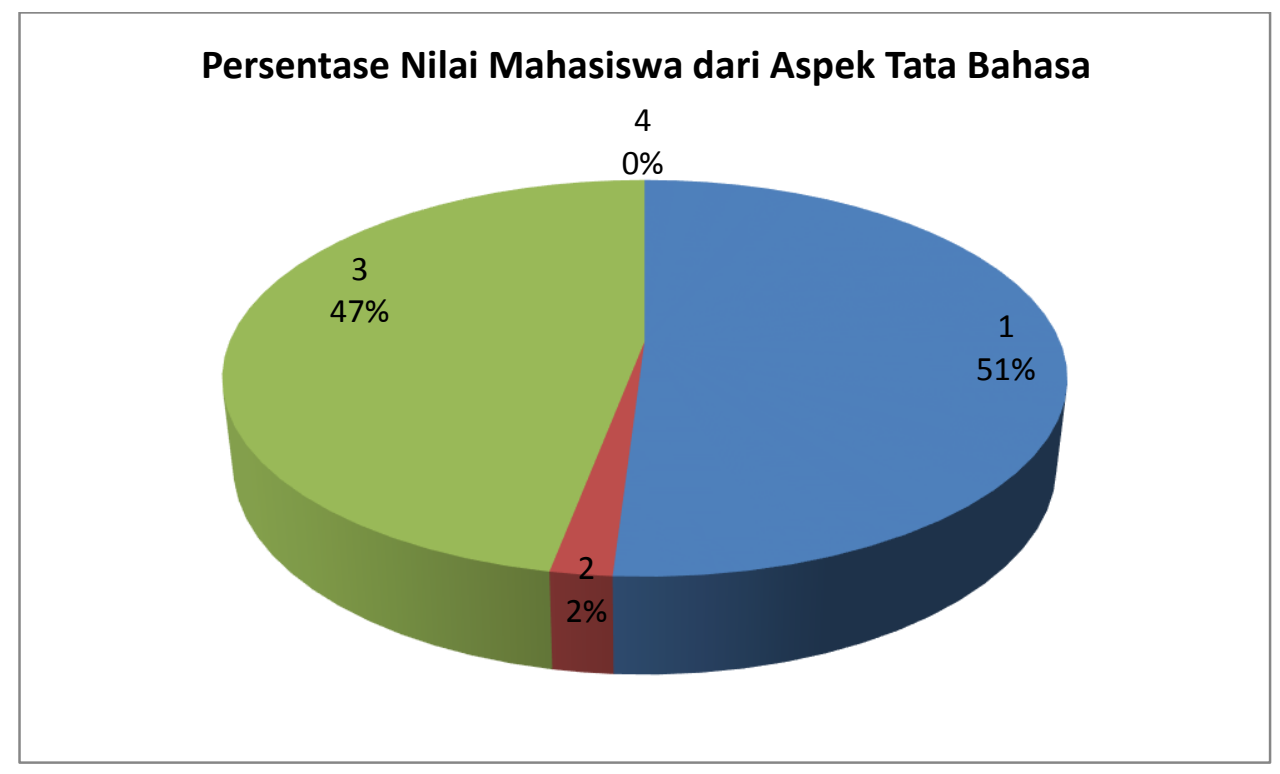

Gambar 4. Grafik Nilai Mahasiswa dari Aspek Bahasa

Dilihat dari diagram pie di atas maka dari 100 responden dapat diketahui bahwa mahasiswa yang mendapat nilai 1 berjumlah sangat besar yaitu $51 \%$. Sedang mahasiswa yang mendapat nilai poin 2 berjumlah $2 \%$ saja berkategori cukup. Mahasiswa yang mempunyai nilai poin 3 ada $47 \%$ yang merupakan kategori baik. Dan mahasiswa yang punya nilai 4 atau sangat baik pada aspek organisasi ini adalah 0\%. Atau tidak ada Sehingga bisa ditarik kesimpulan bahwa pada aspek tata bahasa atau grammar ini sebagian besar mahasiswa berkategori kurang karena lebih dari $50 \%$ berada pada poin 1 . Hal ini berarti tingkat kesalahan pada aspek tata bahasa adalah tinggi. 
Dari aspek kosakata, penulisan paragraf argumentasi mahasiswa dapat dilihat dari diagram pie di bawah ini:

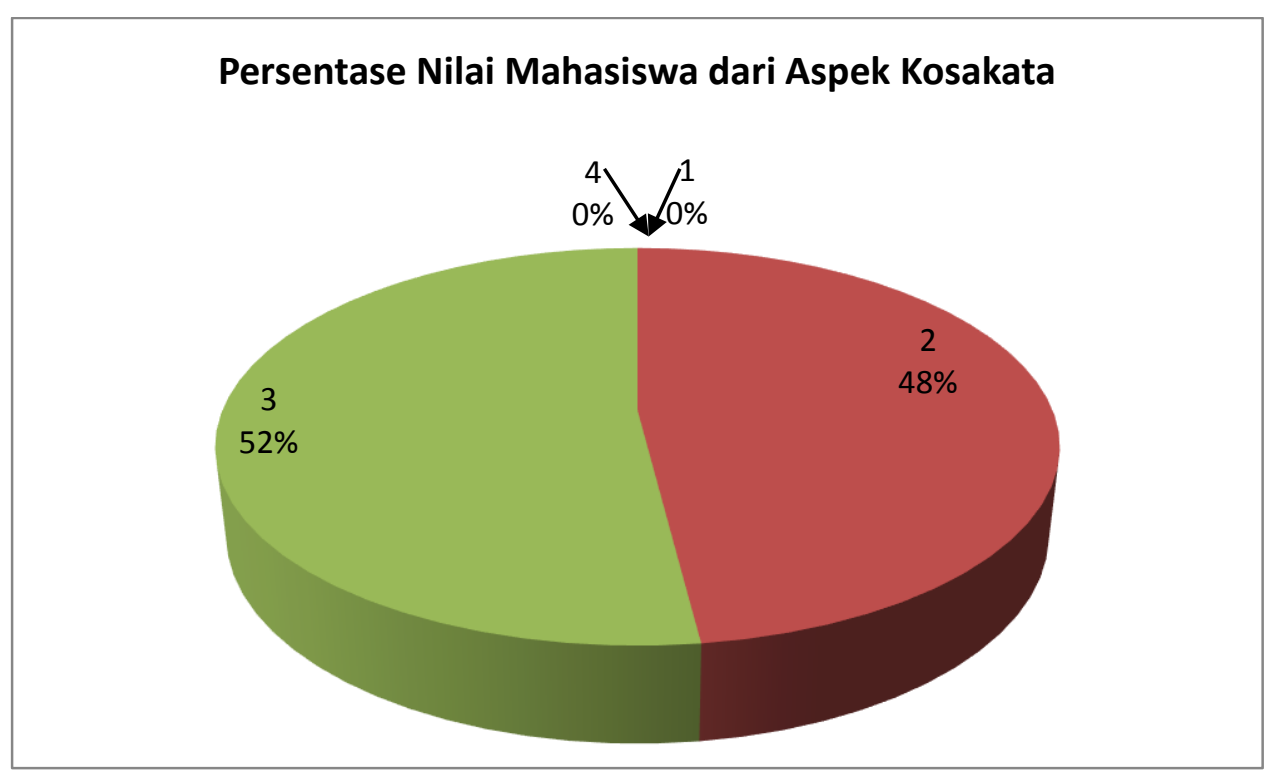

Gambar 5. Grafik Nilai Mahasiswa dari Aspek Kosakata

Dilihat dari diagram pie di atas maka dari 100 responden dapat diketahui bahwa mahasiswa yang mendapat nilai 1 berjumlah $0 \%$ atau tidak seorangpun. Sedang mahasiswa yang mendapat nilai poin 2 berjumlah $48 \%$ yang berkategori cukup. Mahasiswa yang mempunyai nilai poin 3 ada 52\% yang merupakan kategori baik. Dan mahasiswa yang punya nilai 4 atau sangat baik pada aspek kosakata ini adalah $0 \%$ atau tidak ada. Sehingga bisa ditarik kesimpulan bahwa pada aspek tata bahasa atau grammar ini sebagian besar mahasiswa berkategori cukup baik cenderung baik atau tingkat kesalahan yang dibuat siswa rendah. Hal ini berarti tingkat kesalahan pada aspek kosakata adalah rendah. 


\section{KESIMPULAN DAN SARAN}

\section{Kesimpulan}

1. Penulisan paragraf argumentasi merupakan ketrampilan menulis dalam bahasa Inggris yang dapat menumbuhkan ide gagasan kreatif siswa.

2. Disamping itu juga sebagai wadah siswa dalam mengekspresikan opini atau pendapat tentang suatu hal yang direpresentasikan dengan tema Bahasa Inggris Menurut Anda.

3. Hasil tes yang diperoleh dari analisa data terkumpul adalah bahwa penulisan atau writing siswa paragraf argumentasi sudah cukup baik.

4. Ditinjau dari aspek-aspek penulisan paragraf argumentasi yang baik, diperoleh data analisa aspek isi, organisasi, dan kosakata adalah baik atau bagus. Sedangkan error atau kesalahan yang banyak dibuat siswa ada pada aspek tata bahasa atau grammar bahasa Inggris.

\section{Saran}

1. Perlu diberikan jam praktek yang cukup untuk mata kuliah Bahasa Inggris agar siswa lebih menguasai ketrampilan bahasa Inggris terutama writing dengan lebih baik.

2. Pendekatan yang perlu diperhatikan adalah strategi atau teknik mengajar tata bahasa atau grammar bahasa Inggris sehingga penyerapan materi oleh siswa dapat lebih maksimal.

3. Perlu adanya pengembangan materi yang lebih baik lagi bagi siswa non-bahasa Inggris terutama grammar terhadap writing bahasa Inggris. 


\section{UCAPAN TERIMAKASIH}

Penulis mengucapkan terimakasih kepada seluruh mahasiswa dari berbagai jurusan nonBahasa Inggris Politeknik Negeri Jember yang menjadi subyek dalam penelitian ini serta kepada semua pihak yang berkontribusi atas terlaksananya penelitian ini. 


\section{DAFTAR PUSTAKA}

Arikunto, Suharsimi. 1998. Prosedur Penelitian: Suatu Pendekatan Praktek. Jakarta: Rineka Cipta

Ary, D., Jacobs, L.C. \&Razavieh, A. 2002. Introduction to Research in Education(6 $6^{\text {th }}$ ed). New York: Wadsworth/Thomson Learning

Brown, H. D. 2003. Language Assesment: Principles and Classroom Practice. White Plain, N.Y: Pearson Education

Brown, H.D. 2007b. Principles of Language Teaching and Learning, $4^{\text {th }}$ ed. New York: Longman

Celce-Murcia, M., \&Olshtain, E. 2000.Discourse and Context in Language Teaching: A Guide for Language Teachers. Cambridge: Cambridge University Press

Coffin, C. 2003. Teaching Academic Writing. Centre for Language and Communication, The Open University, UK.

Corder, S.P. 1981. Error Analysis and Inter-language. Oxford: Oxford University Press. for Language Teachers. Cambridge: Cambridge University Press

Earner, R. 1997. Content Area Literacy. Teaching for Today and Tomorrow. New York: Delmar. Regional Language Center

Gebhard, J.G. 2000. Teaching English as a Foreign language. Ann Arbor: The University of Michigan Press

Huda, N. 1999. Language Learning and Teaching. Malang: Universitas Negeri Malang Publisher

Hornby, A.S. 1995. Oxford Advance Learner's Dictionary of Current English. Fifth Edition. Oxford: Oxford University Press.

Newman, W.L. 2002. Social Research Methods: Qualitative and Quantitative Approaches. Needham Heights: Pearson Education Company.

Nunan, D. 1999. Second Language Teaching and Learning. Boston: Heinle \& Heinle Publisher

O’ Malley, J.M., \&Pearse, L.V. 1996. Authentic Assessment for English Language Learners: Practical Approaches for Teachers. Boston: Addison-Wesley Publishing Company, Inc.

Oshima, Alice. A Writing and Sentence Structure Workbook for International Students. Addison Wesley. Publishing Company.

Owen, Jr. R. E. 2008. Language Development: An Introduction. Boston: Pearson Education, Inc. 
Penny, Ur. 1996. A Course in Language Teaching, Practice, adn Theory. London: Cambridge University Press.

Richards, J. C. 1992. The Language Teaching Matrix. Cambridge : Cambridge University Press.

Rivers, Wilga M. 1981. Teaching Foreign Language .Skills. Chicago the University of Chicago Press

Yin, R. K. (2003).Case Study Research: Design and Methods (3rd ed.). Thousand Oaks, CA: Sage

Http: //gerrytri.blogspot.com/2013/06/teknik-pengambilan-sampel-htm.html 